\title{
Expert Meeting: Optimized Heating Systems Using Condensing Boilers and Baseboard Convectors
}

\section{Arena}

Steven Winter Associates

January 2013 


\section{NOTICE}

This report was prepared as an account of work sponsored by an agency of the United States government. Neither the United States government nor any agency thereof, nor any of their employees, subcontractors, or affiliated partners makes any warranty, express or implied, or assumes any legal liability or responsibility for the accuracy, completeness, or usefulness of any information, apparatus, product, or process disclosed, or represents that its use would not infringe privately owned rights. Reference herein to any specific commercial product, process, or service by trade name, trademark, manufacturer, or otherwise does not necessarily constitute or imply its endorsement, recommendation, or favoring by the United States government or any agency thereof. The views and opinions of authors expressed herein do not necessarily state or reflect those of the United States government or any agency thereof.

Available electronically at http://www.osti.gov/bridge

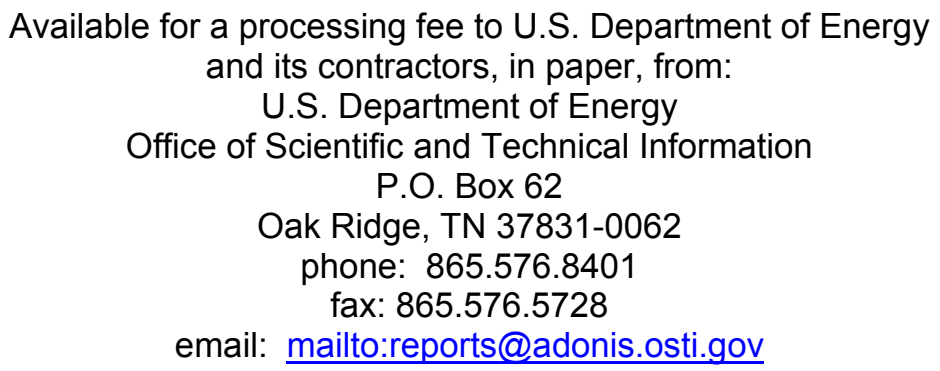

Available for sale to the public, in paper, from:

U.S. Department of Commerce

National Technical Information Service

5285 Port Royal Road

Springfield, VA 22161

phone: 800.553 .6847

fax: 703.605 .6900

email: orders@ntis.fedworld.gov

online ordering: http://www.ntis.gov/ordering.htm 


\title{
Expert Meeting: Optimized Hydronic Heating Systems Using Condensing Boilers and Baseboard Convectors
}

\author{
Prepared for: \\ The National Renewable Energy Laboratory \\ On behalf of the U.S. Department of Energy's Building America Program \\ Office of Energy Efficiency and Renewable Energy \\ 15013 Denver West Parkway \\ Golden, CO 80401 \\ NREL Contract No. DE-AC36-08GO28308 \\ Prepared by: \\ L. Arena \\ Steven Winter Associates, Inc. \\ of the \\ Consortium for Advanced Residential Buildings (CARB) \\ 61 Washington Street \\ Norwalk, CT 06854 \\ NREL Technical Monitor: Cheryn Metzger \\ Prepared under Subcontract No. KNDJ-0-40342-00
}

January 2013 
[This page left blank] 


\section{Contents}

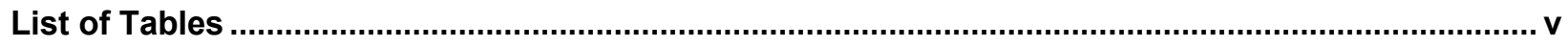

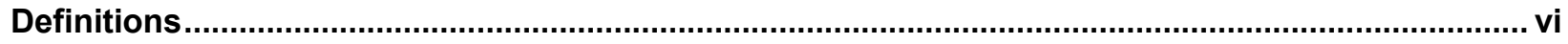

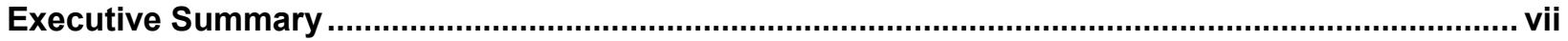

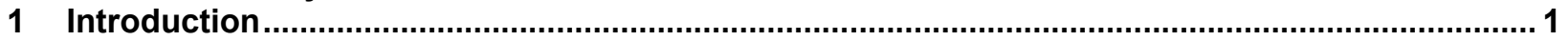

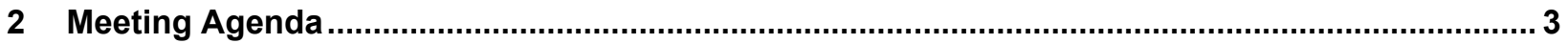

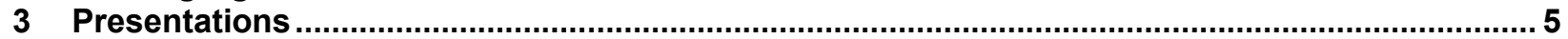

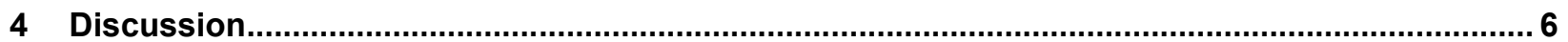

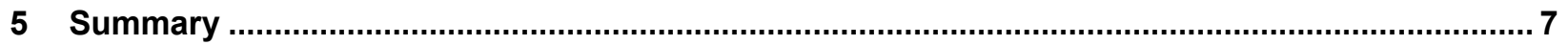

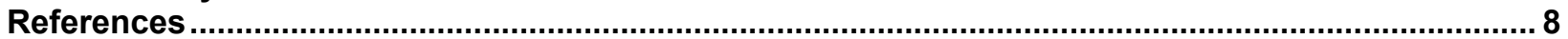

Appendix A: Presentation by Lois Arena, Steven Winter Associates, Inc........................................ 9

Appendix B: Updated Presentation by Xia Fang, National Renewable Energy Laboratory .............. 47

\section{List of Tables}

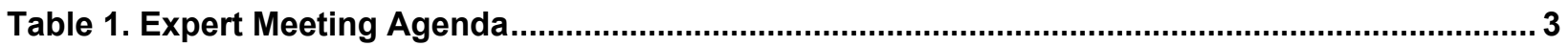

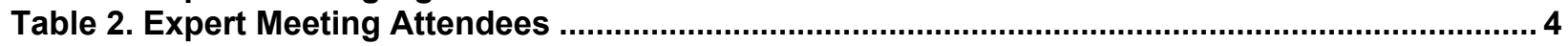

Unless otherwise noted, all tables were created by CARB. 


\section{Definitions}

BEopt

BNL

CARB

DOE

OAT

VFD
Building Energy Optimization

Brookhaven National Laboratory

Consortium for Advanced Residential Buildings

U.S. Department of Energy

Outside air temperature

Variable-frequency drive 


\section{Executive Summary}

On August 11, 2011, a Building America Expert Meeting was held to review and discuss results and future plans for research to improve the performance of hydronic heating systems using condensing boilers and baseboard convectors. The meeting was held in Denver, Colorado, in conjunction with the Building America Residential Energy Efficiency Technical Update Meeting. A meeting objective was to create an opportunity for other Building America teams and industry experts to offer feedback and specific suggestions for the planned research.

Lois Arena of Steven Winter Associates summarized the findings from previous Consortium for Advanced Residential Buildings (CARB) field monitoring research and presented the plan for further research to be conducted next year. CARB has been collaborating with Brookhaven National Laboratory (BNL) and industry manufacturing partners to design, install, and monitor condensing boiler space and water heating systems under occupied conditions. Previous research included the monitoring of condensing boilers in six existing homes, targeted bench top testing by BNL, and monitoring of CARB-designed hydronic heating systems in three new homes.

Xia Fang of the National Renewable Energy Laboratory presented preliminary energy simulation results and identified gaps in modeling capability. Additional modeling work was done based upon comments raised during the meeting. An updated presentation of findings is included as an appendix to this report. 


\section{Introduction}

With annual fuel utilization efficiencies around 95\%, condensing boilers and furnaces promise significant energy savings by recovering the latent energy of flue gas water vapor. Condensing boilers paired with low-temperature baseboard heating systems are one of the most cost-effective methods for heating high performance, and thus low load, homes. Ducted systems (furnaces and hydro-air systems) are often subject to reduced efficiencies resulting from duct leakage and fan energy requirements, and other hydronic distribution systems, such as radiant-floor systems and some specialized cast-aluminum radiation systems, are far more expensive.

Although condensing boilers promise to deliver substantial improvements over conventional boilers, condensing boilers as typically installed (according to common practice and manufacturer recommendations) do not achieve consistent flue gas condensation. To ensure condensation, the return temperature to the boiler must be below the flue gas saturation temperature, which is generally $54^{\circ} \mathrm{C}\left(130^{\circ} \mathrm{F}\right)$ for natural gas equipment (Butcher 2006).

For Building America to achieve its goals, it is important that applications of condensing boiler technology reliably achieve the intended efficiency and energy savings. In response to this need, CARB teamed with the New York State Energy Research and Development Authority, Ithaca Neighborhood Housing Services, and Brookhaven National Laboratory to evaluate the performance of condensing boilers using baseboard convector delivery systems. Specific research objectives included: (1) evaluating and defining the optimal operating parameters of the condensing-boiler/hot-water baseboard combination; (2) evaluating and defining the optimal operating parameters of the condensing boiler/indirect domestic hot water combination; (3) testing those findings in real-world residential settings; and (4) documenting those parameters in a technically accurate, installer friendly manner.

The initial phase of the project involved monitoring boiler performance in six existing homes in Ithaca, NY, beginning in late January 2009 and concluding in August 2009. In the next phase, information gained from the first phase was used to design and size systems for three new homes also located in Ithaca. Boiler performance in the new homes was tested and monitored to further define the best design parameters to ensure maximum boiler efficiencies.

Research findings were presented to industry leaders at a Building America Expert Meeting in October 2010, and although there was much agreement and acceptance of the issues presented, no agreement as to the best solutions was reached and further research was encouraged. Thus, the objectives of the planned research are as follows:

- Evaluate and define the optimal combinations of components and plumbing configuration to ensure highly efficient, reliable condensing boiler performance.

- Test those findings in real-world residential settings.

- Gain recognition and acceptance from the industry for the new designs.

- Document those parameters in a technically accurate, installer friendly manner.

- Disseminate the results to the larger residential building industry. 
During the expert meeting held on August 11, 2011, the details of the test plan were reviewed and discussed. A goal of the meeting was to determine whether the planned research was appropriate and comprehensive. 


\section{Meeting Agenda}

The meeting was held at the Renaissance Hotel in Denver on August 11, the third day of the Building America Residential Energy Efficiency Technical Update Meeting. The meeting agenda and attendees are presented in Tables 1 and 2, respectively.

Table 1. Expert Meeting Agenda

\begin{tabular}{|c|c|c|}
\hline Time & Item & Presenter/Facilitator \\
\hline 9:00-9:05 & Welcome and Meeting Overview & Bill Zoeller, CARB \\
\hline 9:05-10:00 & $\begin{array}{c}\text { Previous Research: monitoring and evaluations of } 6 \\
\text { homes (Phase I and Phase II) } \\
\text { Benchtop research conducted by Dr. Thomas } \\
\text { Butcher, Brookhaven National Laboratory } \\
\text { Conclusions and open questions based on Phase I and } \\
\text { Phase II results } \\
\text { Emerging Technologies (VFD pumps, Versa-Hydra, } \\
\text { etc.) } \\
\text { Phase III: Proposed designs, collaboration with w/ } \\
\text { industry partners. } 3 \text { new homes with } 3 \text { different } \\
\text { systems. }\end{array}$ & Lois B. Arena, CARB \\
\hline $10: 00-10: 30$ & $\begin{array}{c}\text { Analysis of condensing boiler modeling in homes } \\
\text { using BEopt/DOE-2 vs. BEopt/EnergyPlus } \\
\text { Addressing Issues with OAT reset with respect to } \\
\text { modeling } \\
\text { Performance curve implementation issues in } \\
\text { EnergyPlus vs. DOE-2 }\end{array}$ & Xia Fang, NREL \\
\hline $10: 30-10: 55$ & $\begin{array}{c}\text { Feedback, questions, suggestions from } \\
\text { teams/attendees }\end{array}$ & All \\
\hline $10: 55-11: 00$ & Closing Remarks and Next Steps & Bill Zoeller, CARB \\
\hline
\end{tabular}

Notes: VFD, variable-frequency drive; BEopt, Building Energy Optimization; OAT, outside air temperature; DOE, U.S. Department of Energy 
Table 2. Expert Meeting Attendees

\begin{tabular}{|c|c|c|}
\hline Name & Company & E-Mail Address \\
\hline Charles Adams & $\begin{array}{l}\text { A.O. Smith Corporate Technology } \\
\text { Center, Milwaukee, WI }\end{array}$ & cadams@aosmith.com \\
\hline Lois Arena & $\begin{array}{c}\text { Steven Winter Associates, Inc., } \\
\text { Norwalk, CT }\end{array}$ & larena@swinter.com \\
\hline David Bohac & $\begin{array}{l}\text { Center for Energy and } \\
\text { Environment, Minneapolis, MN }\end{array}$ & dbohac@mncee.org \\
\hline Larry Brand & $\begin{array}{c}\text { Gas Technology Institute, } \\
\text { Des Plaines, IL }\end{array}$ & larry.brand@gastechnology.org \\
\hline Kim DeVoe & City of Fort Collins, CO & kdevoe@ffgov.com \\
\hline Cheryn Engebrecht & $\begin{array}{l}\text { National Renewable Energy } \\
\text { Laboratory, Golden, CO }\end{array}$ & Cheryn.engebrecht@nrel.gov \\
\hline Xia Fang & $\begin{array}{l}\text { National Renewable Energy } \\
\text { Laboratory, Golden, CO }\end{array}$ & xia.fang@nrel.gov \\
\hline Dianne Griffiths & Steven Winter Associates, Inc. & dgriffiths@swinter.com \\
\hline Philip Kerrigan & Building Science Corporation & phil@buildingscience.com \\
\hline Bill Zoeller & Steven Winter Associates, Inc. & wzoeller@swinter.com \\
\hline
\end{tabular}




\section{Presentations}

Lois Arena's presentation (Appendix A) reviewed the earlier research findings and detailed the specific designs to be installed and monitored in the next phase of research. She had given a more detailed presentation of the research findings the previous day as part of the Technical Update Meeting.

Xia Fang's presentation reviewed her initial effort to model the performance of condensing boilers and control strategies using EnergyPlus. A work-around using performance curves was utilized for the current version of EnergyPlus. Xia noted that more data should be gathered to validate the performance map used. Preliminary modeling results did not demonstrate substantial energy savings, but the system capacities were not optimized for each alternative modeled. 


\section{Discussion}

The modeling results were presented as preliminary and several suggestions were made. The performance specifications for the modeled home, specifically the infiltration assumption, were questioned, and it was recommended that two house models would be appropriate - a new, tightly constructed home and an existing home. Utilities need to understand the impacts of different parameters to justify their programs. This additional modeling work was done after the meeting. Those findings are presented in the updated presentation located in Appendix B.

There was also a concern that the cost of the OAT reset control applied for the cost-effectiveness analysis was too high. The preliminary conclusions on cost effectiveness have been removed from the updated presentation.

Zone valve reliability was discussed with the group. The builder partnering with CARB for this research prefers to use circulators for each heating zone as opposed to zone valves. He believes that zone valves fail every few years and the cost to replace them outweighs the savings of installing high efficiency systems. The group was asked their opinion on this issue. None of the participants had experience or direct knowledge with the reliability of zone valves versus circulators.

Larry Brand noted that the Gas Technology Institute has tested pumps in its laboratory and agreed that the trades believe in the "bigger pump is better" philosophy.

Installing condensing boilers in a retrofit application was discussed. It was agreed that, while baseboard convectors are probably adequate in existing homes because they are traditionally grossly oversized, existing high mass radiators may not be a feasible heat emitter when combined with a condensing boiler in a retrofit application.

Charles Adams noted that AO Smith has acquired Lochinvar, and they might be interested in partnering with us during the next phase. It was mentioned that Lochinvar boilers have a built-in primary loop, which is one of the design elements that CARB is trying to eliminate because it contributes to higher return water temperatures and lower installed efficiencies. The designs currently under consideration eliminate primary/secondary loop configurations all together.

The application of hydrocoil systems was briefly discussed and, while of interest, it was acknowledged that they are not within the scope of this research. 


\section{Summary}

During this expert meeting, the details of the test plan to be implemented by CARB during the 2011/2012 winter were reviewed and discussed. Meeting attendees were asked if the test plan was appropriate and comprehensive and if there were other design configurations that should be considered. Attendees supported the test plan and no alternative design suggestions were made at, or subsequent to, the meeting. Meeting attendees were invited to provide input to the test plan and proposed designs at any time. 


\section{References}

Butcher, T. (2006). "Condensing Boilers and Baseboard Hydronic Systems.” ASHRAE Transactions (112:part 1). 


\section{Appendix A: Presentation by Lois Arena, Steven Winter Associates, Inc.}




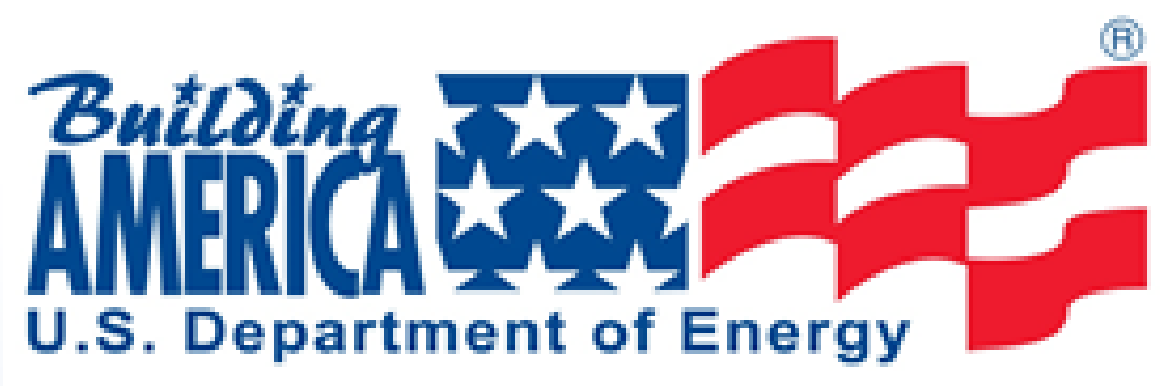

\title{
"Experts Meeting" Condensing Boilers
}

\author{
August 11, 2011 \\ 9:00 am - 11:00 pm \\ Denver, CO
}




\section{Overview of Presentation}

- Why research boilers?

- Previous Research - 3 Phases:

- Monitoring and Evaluation of 6 Existing Homes

- Bench top Research from Thomas Butcher at BNL

- Design, Monitoring \& Evaluation of 3 New Homes

- Next Round:

- Close collaboration w/ Industry Partners

- 3 New Homes, 3 Different Systems 


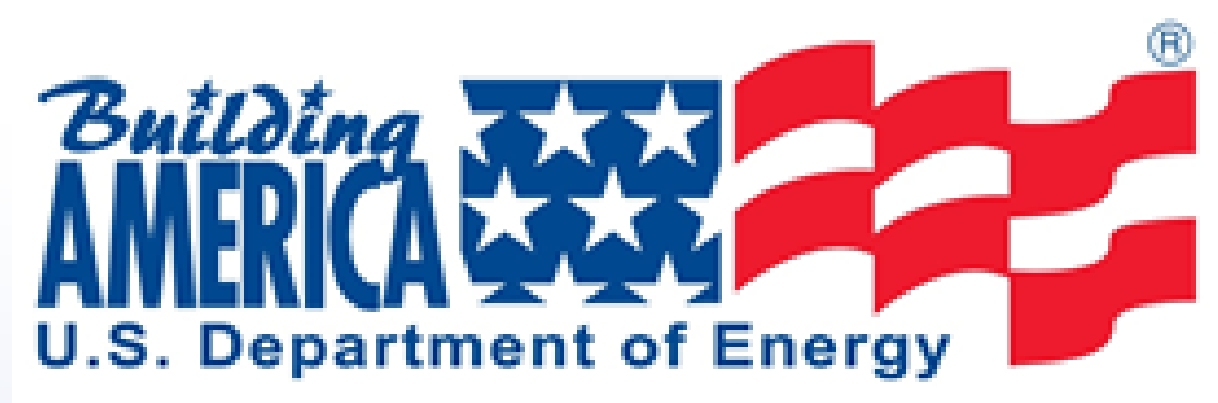

\section{WHY RESEARCH BOILERS?}




\section{Relevance of Research}

- 115 million existing homes in the US - 14 million $(11 \%)$ are heated with a steam or hot water system

- Modulating capability makes them an excellent option for low-load homes

- Combined with baseboard convectors = low-cost, energy efficient solution for high-efficiency residential space heating in cold climates 


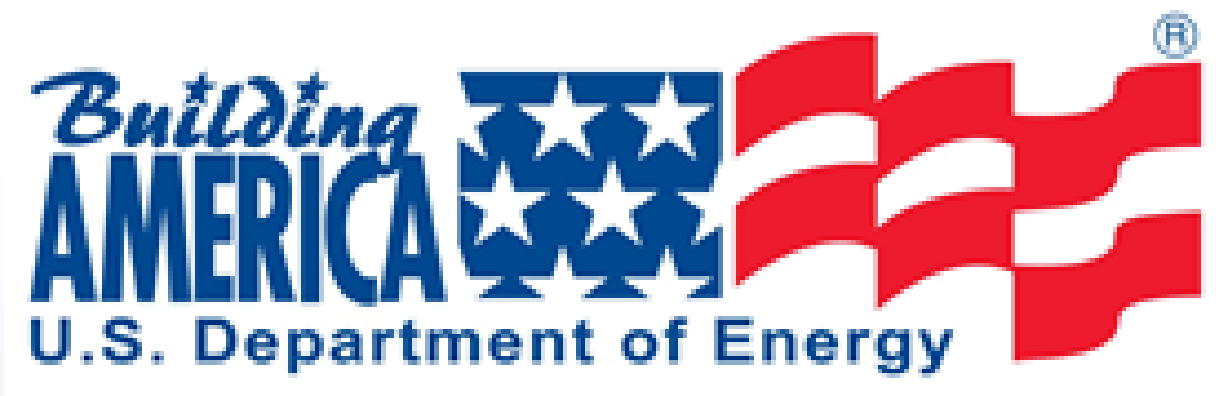

\section{PREVIOUS RESEARCH}




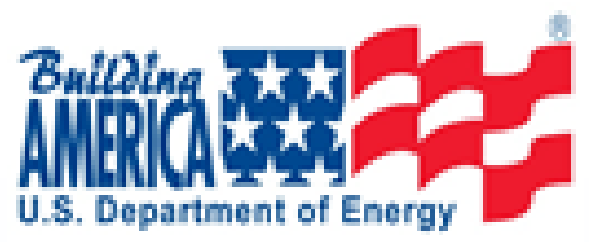

\section{Phase I-Space Heat Summary}

Table 1. Summary of Space Heating Operating Conditions from Existing Home Monitoring

\begin{tabular}{|c|c|c|c|c|c|c|c|c|c|c|}
\hline \multirow[b]{2}{*}{ House } & \multirow[b]{2}{*}{$\begin{array}{c}\text { Baseb oard } \\
\text { Length } \\
\mathrm{ft}\end{array}$} & \multirow[b]{2}{*}{$\begin{array}{l}\text { Eailer } \\
\text { Gpacity } \\
\text { kBtuh }\end{array}$} & \multirow[b]{2}{*}{$\begin{array}{c}\forall \text { of } \\
\operatorname{Zones} \\
\#\end{array}$} & \multirow[b]{2}{*}{$\begin{array}{l}\text { Flow } \\
\text { Rate } \\
\text { gpm }\end{array}$} & \multirow{2}{*}{$\begin{array}{c}\text { Frequency } \\
\text { of } \\
\text { Condensing }\end{array}$} & \multirow{2}{*}{$\begin{array}{c}\text { Outdanr } \\
\text { Reset }\end{array}$} & \multicolumn{3}{|c|}{ Boiler Curve Settings [F] } & \multirow[b]{2}{*}{$T_{14 \pi / n}$} \\
\hline & & & & & & & $T_{11, m x}$ & Toutsin & $T_{\text {out,max }}$ & \\
\hline$\$ 1$ & 52 & यกkn Dw & 1 & 3.1 & $69 \%$ & $\mathrm{Y}$ & 190 & 0 & 72 & 95 \\
\hline$\$ 2$ & 39.5 & 50 & 2 & 5.3 & $59 \%$ & $\mathrm{Y}$ & 195 & 5 & 69 & 95 \\
\hline \pm 3 & 61 & 80 & 3 & 4.8 & $60 \%$ & $\mathrm{Y}$ & 180 & 5 & 68 & 95 \\
\hline$\$ 4$ & 32 & 90 & 1 & 3.3 & $20 \%$ & $\mathbb{N}^{2}$ & 200 & 5 & 69 & 95 \\
\hline$\$ 5$ & 41 & 50 & 2 & 5.2 & 149 & $\mathrm{y}^{\mathrm{a}}$ & 195 & 5 & 69 & 145 \\
\hline$\$ 5$ & 54 & 90 & 2 & 4.3 & 169 & $\mathbb{N}$ & 201 & 5 & 69 & 95 \\
\hline
\end{tabular}

${ }^{1}$ Flow rate recorded through primary loop.

"The outda ar revet, althaugh installed, is nat regictering in the control er.

"The minimum boiler supply temperature was set to 145 "F because the toe kick heater in the kitchen wald nat activate below that. 


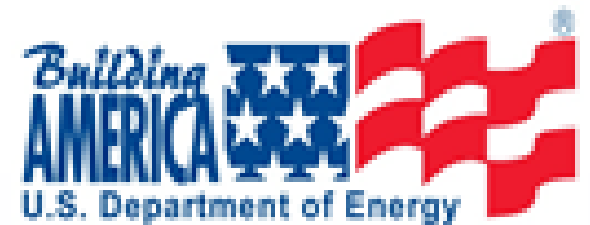

\section{Phase I - DHW Summary}

Table 1. Summary of DHW Operating Conditions from Existing Home Monitoring

\begin{tabular}{|c|c|c|c|c|c|c|c|}
\hline $\begin{array}{c}\text { Hous } \\
\text { e }\end{array}$ & $\begin{array}{c}T_{x, \mathrm{naw}} \\
{ }^{\mathrm{F}} \mathrm{F}\end{array}$ & $\begin{array}{c}\text { Tank } \\
\text { 5etpoint } \\
\text { "F }\end{array}$ & $\begin{array}{l}\text { Tanksixe } \\
\text { gallons }\end{array}$ & $\begin{array}{l}\text { Flow } \\
\text { gpm }\end{array}$ & $\begin{array}{c}\text { \# of } \\
\text { Dccupants }\end{array}$ & $\begin{array}{c}\text { Yof Time } \\
\text { Condensin } \\
\text { g }\end{array}$ & $\begin{array}{c}\text { Data } \\
\text { Interval } \\
\text { minutes }\end{array}$ \\
\hline$\# 1$ & 190 & 125 & 30 & 33 & 2 & $60 \%$ & 15 \\
\hline$\# 2$ & 190 & 115 & 30 & 56 & 2 & 658 & 5 \\
\hline$\# 3$ & 190 & 125 & 40 & 42 & 4 & $44 \%$ & 5 \\
\hline$\# 4$ & 145 & 115 & 30 & 60 & 4 & 368 & 5 \\
\hline$\# 5$ & 100 & 7 & 30 & 5.4 & 3 & 196 & 5 \\
\hline$\# 6$ & 195 & 115 & 30 & 27 & 1 & 356 & 15 \\
\hline
\end{tabular}




\section{Phase I - Key Findings}

- Primary/secondary loop plumbing configuration contributes to higher than optimal return water temperatures to the boiler

- Flow rates are higher than recommended, contributing to higher than optimal return water temperatures.

- Baseboard lengths being installed in these homes are consistent with the lengths needed for a low temperature, low flow system.

- Maximum boiler output temperature is typically set to $180^{\circ} \mathrm{F}$ or higher.

- Boiler supply temps to the domestic hot water tank were set at $180^{\circ} \mathrm{F}$ or higher for 5 of the 6 homes. 


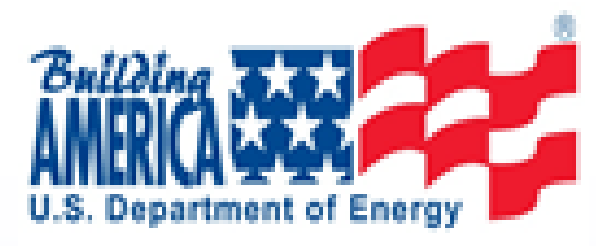

\section{Phase II Bench Top w/ BNL - Objective}

- Blow up the boiler! 


\section{Phase II Bench Top - Key Findings}

- Particularly difficult to blow up the boiler!

- Low mass boiler tested can be operated with:

- flow rates significantly lower, and

- temperature rises significantly higher than the manufacturer's recommendations.

- The boiler pressure should be maintained at the high end of its allowable range. 


\section{Phase III - Objectives}

- Evaluate the plans and specifications for three new homes

- Make design recommendations based on information gained from Phase I

- Monitor the performance of these systems once installed 


\section{Phase III - Design Recommendations}

- Maximum boiler supply temperature should be set to $160^{\circ} \mathrm{F}$;

- Flow rate through each zone should be $1 \mathrm{gpm}$;

- Baseboard sizing was based on an average water temperature of $150^{\circ} \mathrm{F}$;

- 30 gallon, indirect storage tanks controlled by Vision I controller;

- The primary loop should be removed. 


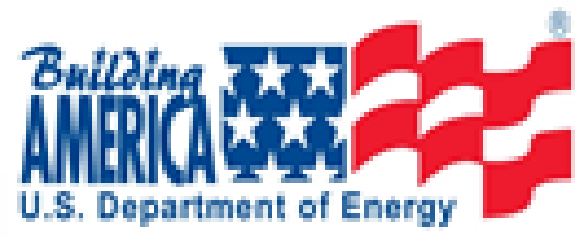

\section{Phase III-Recommended vs. Installed Spec's}

\begin{tabular}{|c|c|c|c|c|c|c|}
\hline \multirow[t]{2}{*}{ Add ress } & \multicolumn{3}{|c|}{ Recommended Sper's } & \multicolumn{3}{|c|}{ Installed 5 per's } \\
\hline & Bailer & Busebourt & DHW & Eqiler & Busebosids & $\mathbf{D H W}$ \\
\hline House $\$ 1$ & $\begin{array}{l}\text { 50 kBtuh } \\
\text { Munchkin } \\
\text { Contendar }\end{array}$ & $\begin{array}{l}26-1^{n t} \text { fagr } \\
22-2^{n} \text { flor }\end{array}$ & 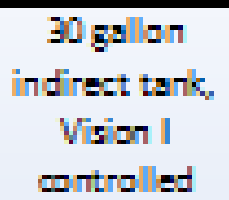 & $\begin{array}{l}\text { BdkEtuh } \\
\text { Mundkin }\end{array}$ & 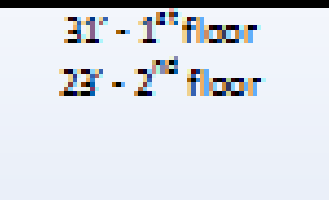 & $\begin{array}{l}40 \mathrm{gal} \text { indirest } \\
\text { tank Vsanl } \\
\text { camtroled but } \\
\text { nateamastbe }\end{array}$ \\
\hline House $\$ 2$ & $\begin{array}{l}\text { 50kBtuh } \\
\text { Munchkin } \\
\text { Contender }\end{array}$ & $\begin{array}{l}21^{\prime \prime}-1^{*} \text { fagr } \\
19^{\prime \prime}-2^{\text {nd }} \text { fagr }\end{array}$ & $\begin{array}{c}\text { 90 gallan } \\
\text { indrat tank } \\
\text { Vsan II } \\
\text { antralled }\end{array}$ & $\begin{array}{c}\text { As } \\
\text { Pleomitends }\end{array}$ & 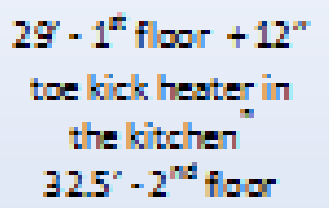 & $\begin{array}{c}\text { As } \\
\text { Regmmend }=d\end{array}$ \\
\hline House $\$ 3$ & $\begin{array}{l}\text { 90 kBtuh } \\
\text { Munchkin } \\
\text { Comtender }\end{array}$ & $\begin{array}{l}19^{\prime}-1^{\mathrm{f}} \text { fagr } \\
16^{\prime}-2^{\mathrm{d}} \text { flogr }\end{array}$ & $\begin{array}{c}\text { 90 gallan } \\
\text { indrect tank } \\
\text { Vsan I } \\
\text { antrallad }\end{array}$ & $\begin{array}{c}\text { As } \\
\text { Recommended }\end{array}$ & 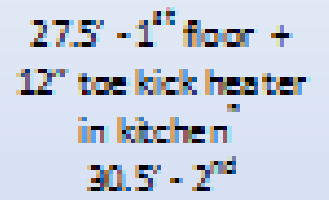 & $\begin{array}{c}30 \mathrm{gal} \text { indirect } \\
\text { tank aquartat } \\
\text { controled }\end{array}$ \\
\hline
\end{tabular}

The tokick hesters provide appraimately 3,100 Btuh at 140 F inlet on low speed. This is a ppraximately squl to 3.5 times the calculated lad far that spare. 


\section{Phase III - “Final” Settings}

U.S. Department of Energy

\begin{tabular}{|c|c|c|c|c|}
\hline & Settlnes & House $\# 1$ & Houst $\# 2$ & House \pm 3 \\
\hline \multicolumn{5}{|l|}{ The rmostets ["F] } \\
\hline \multirow[t]{4}{*}{ an thru Frl } & $\mathrm{Exg} \mathrm{am}$ & $E \boldsymbol{B}$ & $\mathbf{E g}$ & 50 \\
\hline & $900 \mathrm{am}$ & 55 & 52 & $5 \mathbf{5}$ \\
\hline & $500 \mathrm{pm}$ & $\mathbf{s}$ & $\mathbf{E s}$ & $\mathbf{s}$ \\
\hline & $1000 \mathrm{pm}$ & 55 & \pm 2 & $\mathbf{5 5}$ \\
\hline \multirow[t]{2}{*}{ Sat E Sun } & $300 \mathrm{am}$ & 70 & 70 & 70 \\
\hline & $1000 \mathrm{pm}$ & 52 & $E 2$ & 55 \\
\hline \multicolumn{5}{|l|}{ Eollar Sattlnns [F] } \\
\hline & Supply to Iones at SF outslde & 150 & 150 & 150 \\
\hline & supply to zancs at sg'F outs de & 95 & 95 & 95 \\
\hline & Dlferantil to zones & 30 & 30 & 30 \\
\hline & supply to DHW & 150 & 180 & 150 \\
\hline & DHW Tank Satpolnt & $95^{\circ}$ & 119 & $1 \geqslant 0$ \\
\hline \multicolumn{5}{|l|}{ Fump spads [nom] } \\
\hline & $\operatorname{Ian} 1[\operatorname{agn} 2 / \operatorname{Ian} 2]$ & $3.1 / 2.4[\operatorname{lon}\}$ & $3.0 / 2.5[\mathrm{low}]$ & $3.2 / 2.3[10 w)$ \\
\hline & 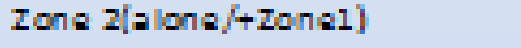 & $3.0 / 2.4|\operatorname{low}|$ & $1.9 / 1.4[\ln \mid \mathrm{n}]$ & $2.5 / 2.1[10 \mathrm{~N}]$ \\
\hline & DHW [alane] & 4.5 & $4.0(\operatorname{low})$ & $4.2[\operatorname{low}]$ \\
\hline
\end{tabular}

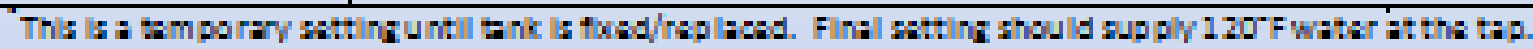

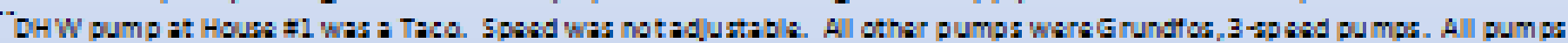
st to "low" weat sonez at Houn $\neq 2$.

\section{HimiliCARB}




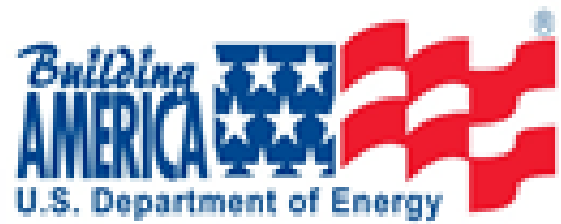 \\ Phase III-Operation Under Design Conditions}
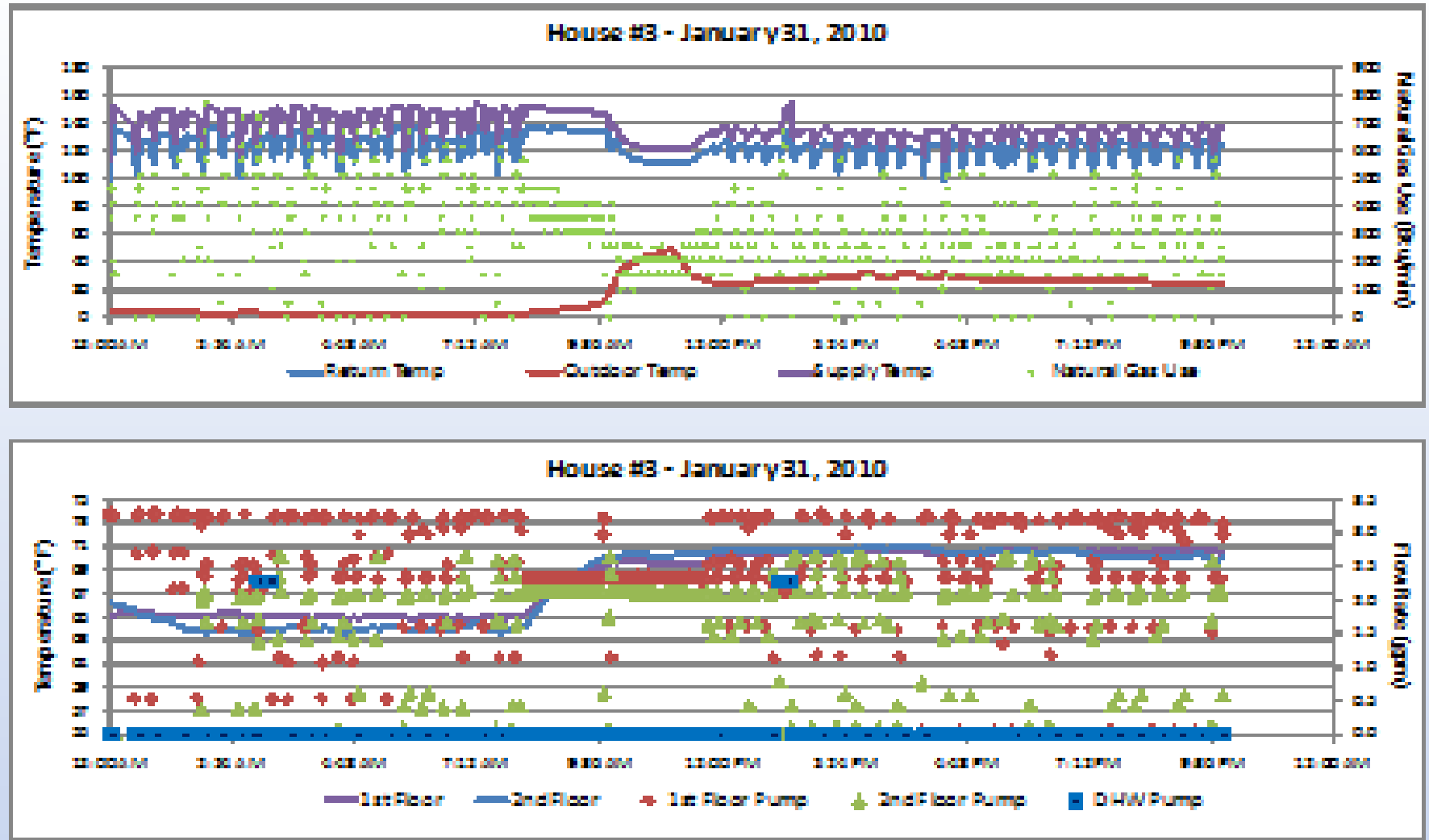

HEIIIHACARB

9 zol1 Steven Winter Assodstes, inc. All rigts nesened. 


\section{Phase III-General Observations at Design}

- Once setpoint is reached, systems don't have trouble maintaining the indoor temperature.

- Boilers often modulate to higher rates even though the lowest rate is over design load.

- Boilers rarely reach maximum firing rates unless DHW calls for heat 


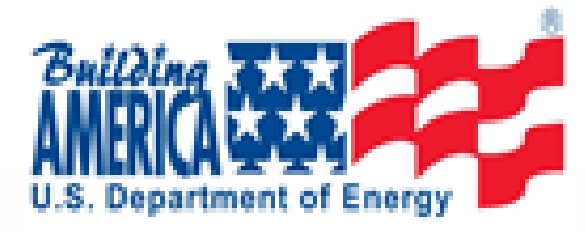

\section{Phase III - General Overview of Performance}

\begin{tabular}{l|ccc|c}
\hline & \multicolumn{3}{|c|}{ Frequency of Condensing (\%) } & $\begin{array}{c}\text { \% of Time Boiler } \\
\text { Fires During Call for } \\
\text { Heat }\end{array}$ \\
\hline House \#1 & Space Heat Only & DHW Only & Overall & 34 \\
House \#2 & 97 & 64 & 97 & 68 \\
House \#3 & 96 & 56 & 93 & 75 \\
\hline
\end{tabular}

97\% of Temps fell in Bins where condensing was predicted. 


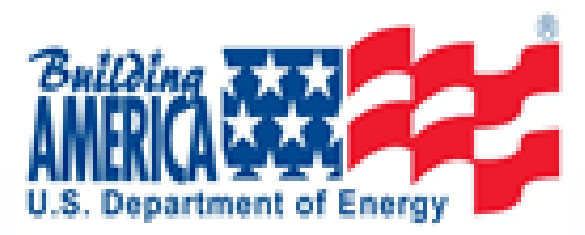

\section{Phase III - Recovery From Setback}

- Recovery was never achieved at House \#1 on the $1^{\text {st }}$ floor.

- Location of outdoor reset sensor is important to system performance

- Recovery time appears to get worse with increasing outdoor temperatures

- Differential setting can affect recovery time

- 2-story configuration may be contributing to recovery lag of the first floor 


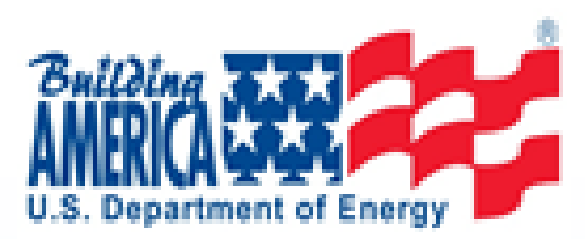

\section{Phase III - No Heat in Swing Seasons}
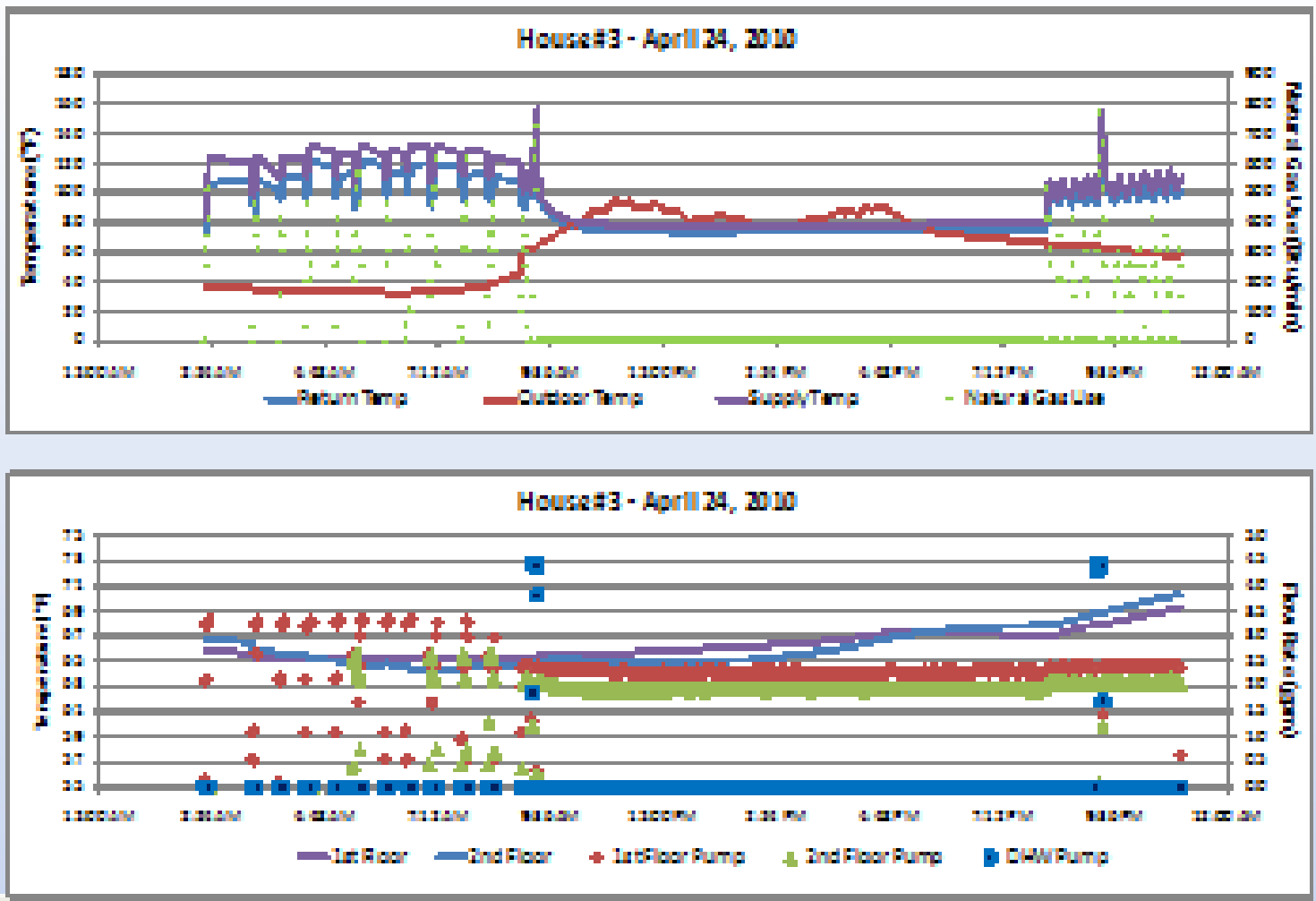


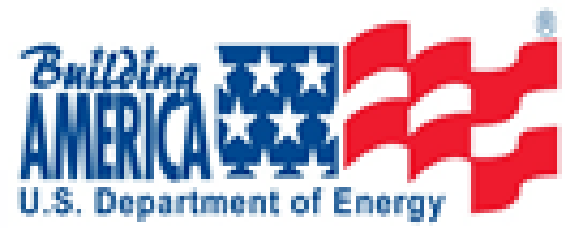

\section{Phase III - Affects of Adjusting $\mathrm{T}_{\text {out,max }}$}

\begin{tabular}{|c|c|c|c|c|c|c|c|c|c|c|c|c|}
\hline \multirow[b]{2}{*}{ Toutms } & \multicolumn{12}{|c|}{$\begin{array}{l}\text { Frequency of Condensing at Different } T_{\mathrm{sms}} \\
\qquad[1,2 \& 3 \mathrm{gpm}]\end{array}$} \\
\hline & & 150 & & & 160 & & & 170 & & & 180 & \\
\hline 68 & $99 \%$ & $91 \%$ & $87 \%$ & $90 \%$ & $80 \%$ & $77 \%$ & $79 \%$ & $68 \%$ & $04 \%$ & $68 \%$ & $57 \%$ & $53 \%$ \\
\hline 70 & $99 \%$ & $90 \%$ & $87 \%$ & $89 \%$ & $79 \%$ & $70 \%$ & $78 \%$ & $60 \%$ & $04 \%$ & $84 \%$ & $54 \%$ & $52 \%$ \\
\hline 72 & $99 \%$ & $90 \%$ & $86 \%$ & $88 \%$ & $78 \%$ & $74 \%$ & $77 \%$ & $64 \%$ & $01 \%$ & $63 \%$ & $52 \%$ & $51 \%$ \\
\hline
\end{tabular}




\section{Phase III - Flow Rates}

Barriers to achieving specified, low-flow rates.

- Contractors don't have standard, simple methods for measuring and/or setting flow rates.

- Until recently, low flow residential pumps for which the flow can be set, have been difficult to find. 


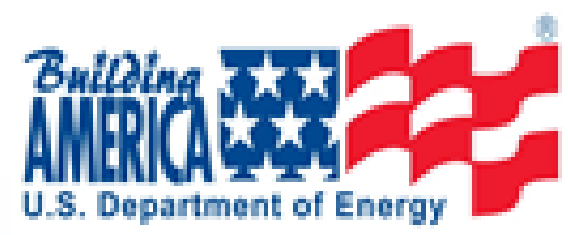

\section{Phase III - Comparison of Boiler Operation at Different Flow Rates}

\begin{tabular}{|c|c|c|c|c|c|c|c|}
\hline $\begin{array}{l}\text { Pump Flows } \\
\text { [gpm] } \\
\text { zonel/zonez }\end{array}$ & $\begin{array}{l}\text { Average } \\
\qquad \Delta \mathrm{T}\end{array}$ & $T_{4, w}$ & $T_{\text {oustwis }}$ & $\begin{array}{l}\text { Maxfling } \\
\text { Rate }\end{array}$ & $\begin{array}{l}\text { Average } \\
\text { Fling Rate }\end{array}$ & $\begin{array}{l}\text { \% Firlng } \\
\text { Durlng Call } \\
\text { for Heat }\end{array}$ & $\begin{array}{l}\text { Recowery } \\
\text { Tlme }\end{array}$ \\
\hline & ${ }^{a} \mathrm{~F}$ & ${ }^{a} \mathbf{F}$ & ${ }^{s} \mathrm{~F}$ & kEtuh & kBtuh & & ${ }^{3} \mathrm{~F} /$ hour \\
\hline $2.5 / 2.4$ & 13 & 126.2 & 29.6 & 65 & 32 & 31 & $0.5 / 0.9$ \\
\hline $0.9 / 1.1$ & 19.3 & 125.5 & 33.5 & 49 & 21 & 47 & $0.35 / 0.35$ \\
\hline
\end{tabular}




\section{Conclusions}

- Little advice on controlling flow rates or setting the boiler response curve;

- Severe over-sizing = excessive cycling and reduced comfort.

- Spike in $\mathrm{T}_{\text {out }}$ could lead to no heat.

- $1^{\text {st }}$ floor zones ran approximately $22-35 \%$ more often than $2^{\text {nd }}$ floor zones. 


\section{Conclusions}

- Primary/secondary loop configuration reduces the frequency of condensing.

- Extreme delays in recovery from setback.

- Outdoor reset and low limit settings on the boiler curve affect response time.

- Components requiring minimum supply water temperature should be spec'd properly. 


\section{Conclusions}

Lots of info on individual components,

BUT

little information explaining best combination of settings when these technologies are combined. 


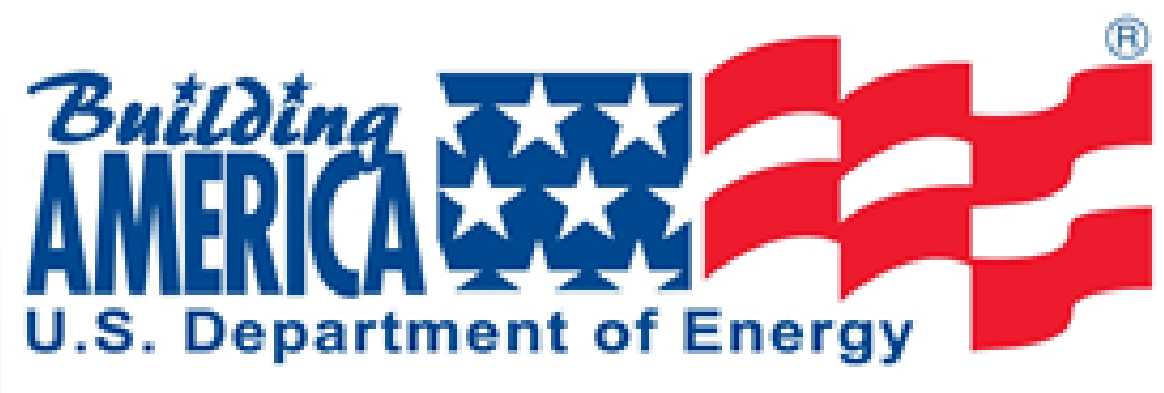

\section{UPCOMING RESEARCH}




\section{Upcoming Research - Goals}

Create system designs that:

- increase condensing frequency,

- reduce recovery time,

- increase reliability, and

- reduce installation complexity with regard to controls and piping configurations. 


\title{
Upcoming Research - Goals
}

\author{
Proven, repeatable, reliable, industry- \\ sanctioned designs.
}




\section{Upcoming Research}

- 3 New Homes

- Similar construction to first round of research

- Applicability to retrofit applications 


\section{Research Question}

- What combination(s) of components - pumps, high efficiency heat sources, plumbing configurations and controls - will result in the highest overall efficiency for a hydronic system where baseboard convectors are used as the heat emitter? 


\section{Research Questions}

- What is the trade-off in efficiency associated with decreased recovery times following setback? Which would result in lower overall energy use - employing thermostat setback with a boost to speed recovery or simply maintaining a constant temperature in the home? 


\section{Upcoming Research}

Will monitor both:

- No setback, constant temperature

- Boost control to override boiler 


\section{Research Questions}

- What is the value of thermal mass in high efficiency boiler systems? 


\section{Research Questions}

- What is the value of thermal mass in high efficiency boiler systems? 


\section{Upcoming Research}

Do these offer:

- Increased annual efficiency?

- Less cycling?

- Increased response time?

- Simplified install? 


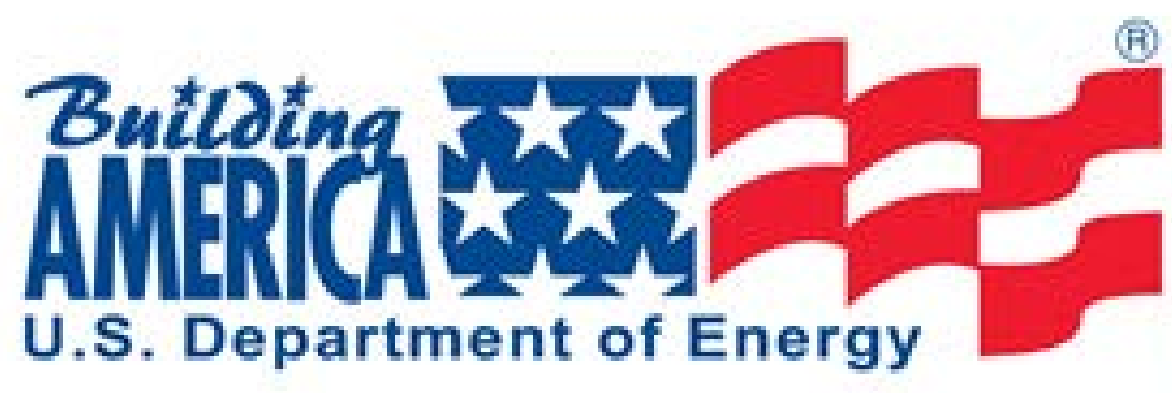

Questions. 


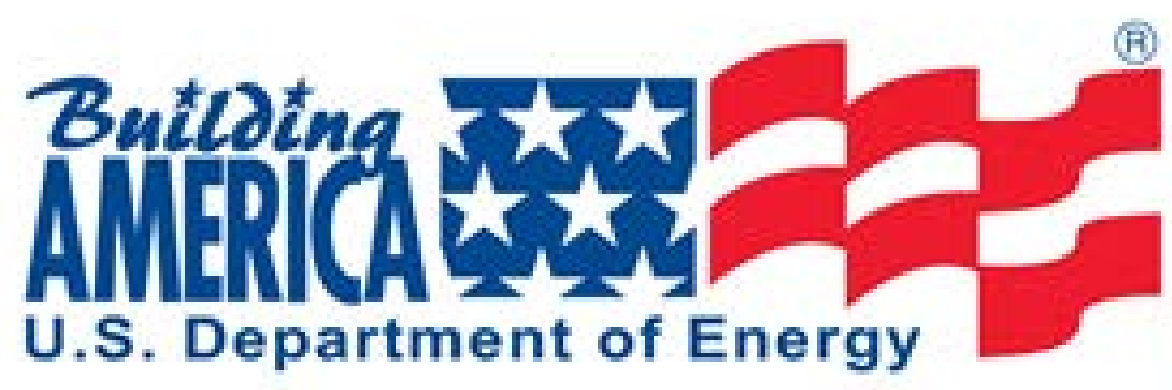

Thank you. 


\section{Appendix B: Updated Presentation by Xia Fang, National Renewable Energy Laboratory}




\section{Residential Condensing Boilers}
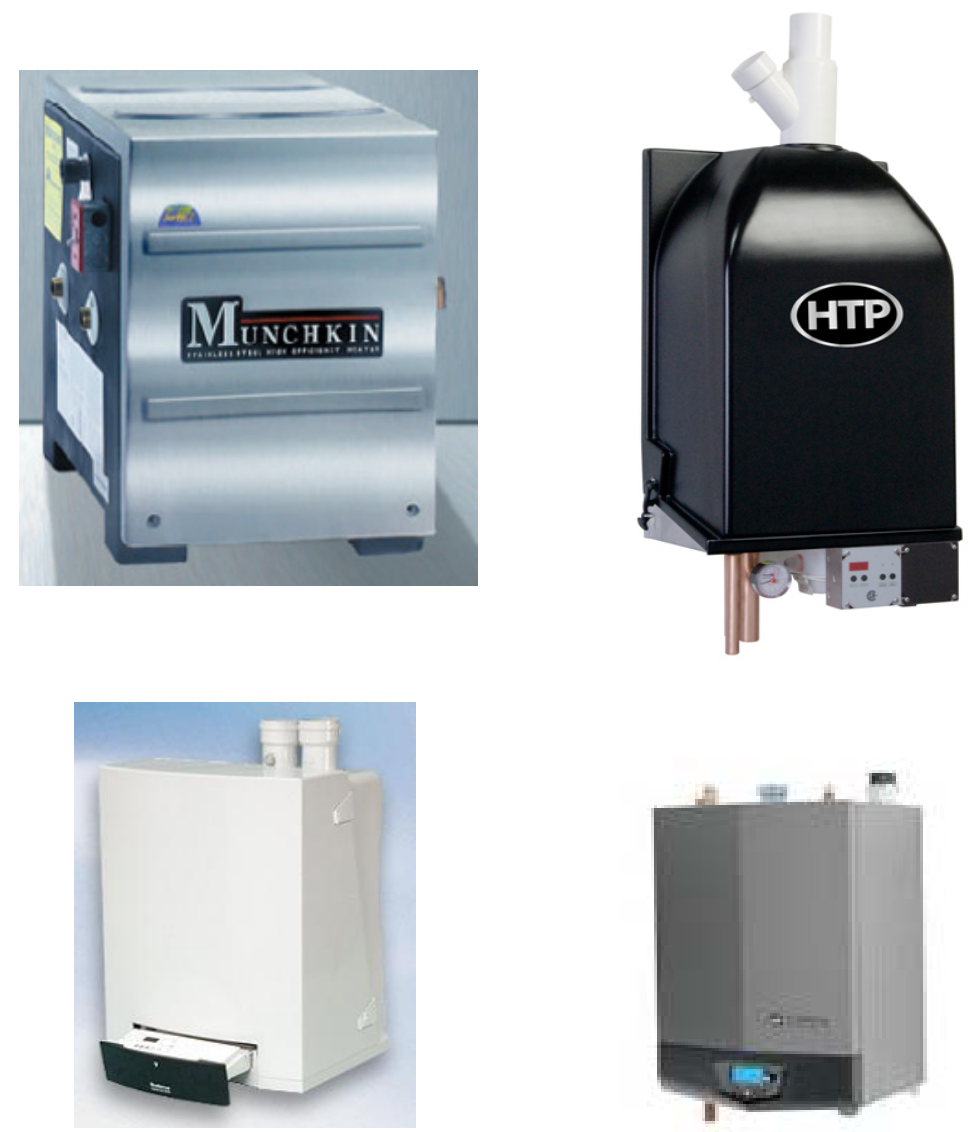

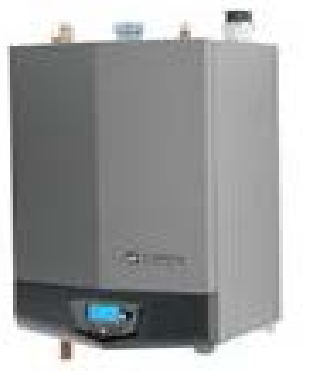

- Thermal efficiency 93\% 98\%

- Fully Modulating 5:1 Turn Down

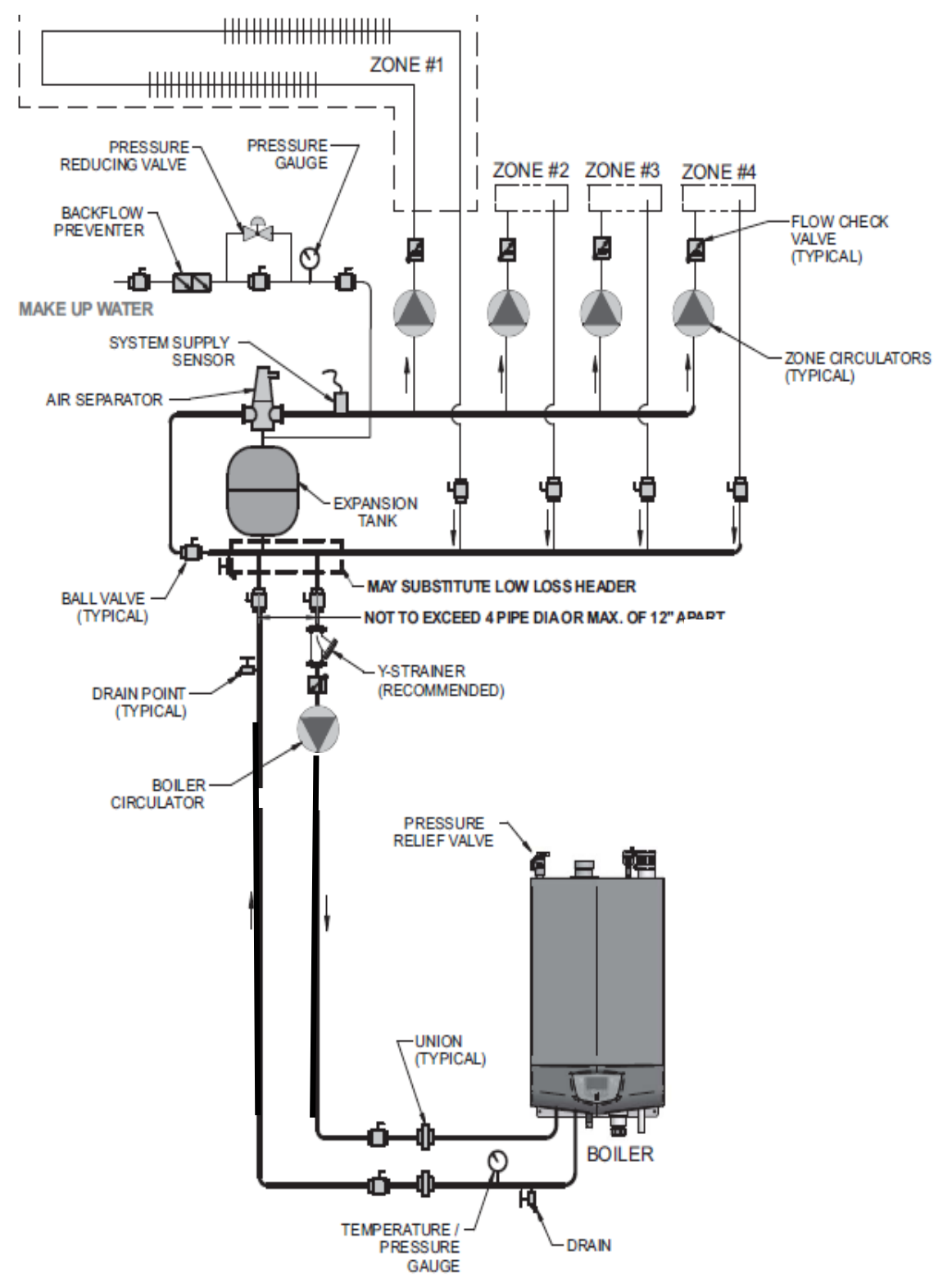




\section{DOE2:}

Thermal Efficiency is a function of return water temperature, default efficiency is rated at $80 \mathrm{~F}$ HWRT.

\section{EnergyPlus:}

EnergyPlus v6.0 uses condensing efficiency as a function of supply water temp instead of return water temp.

New release of $E+v 7$ coming in Dec. Custom EMS program on performance curve as current work round.
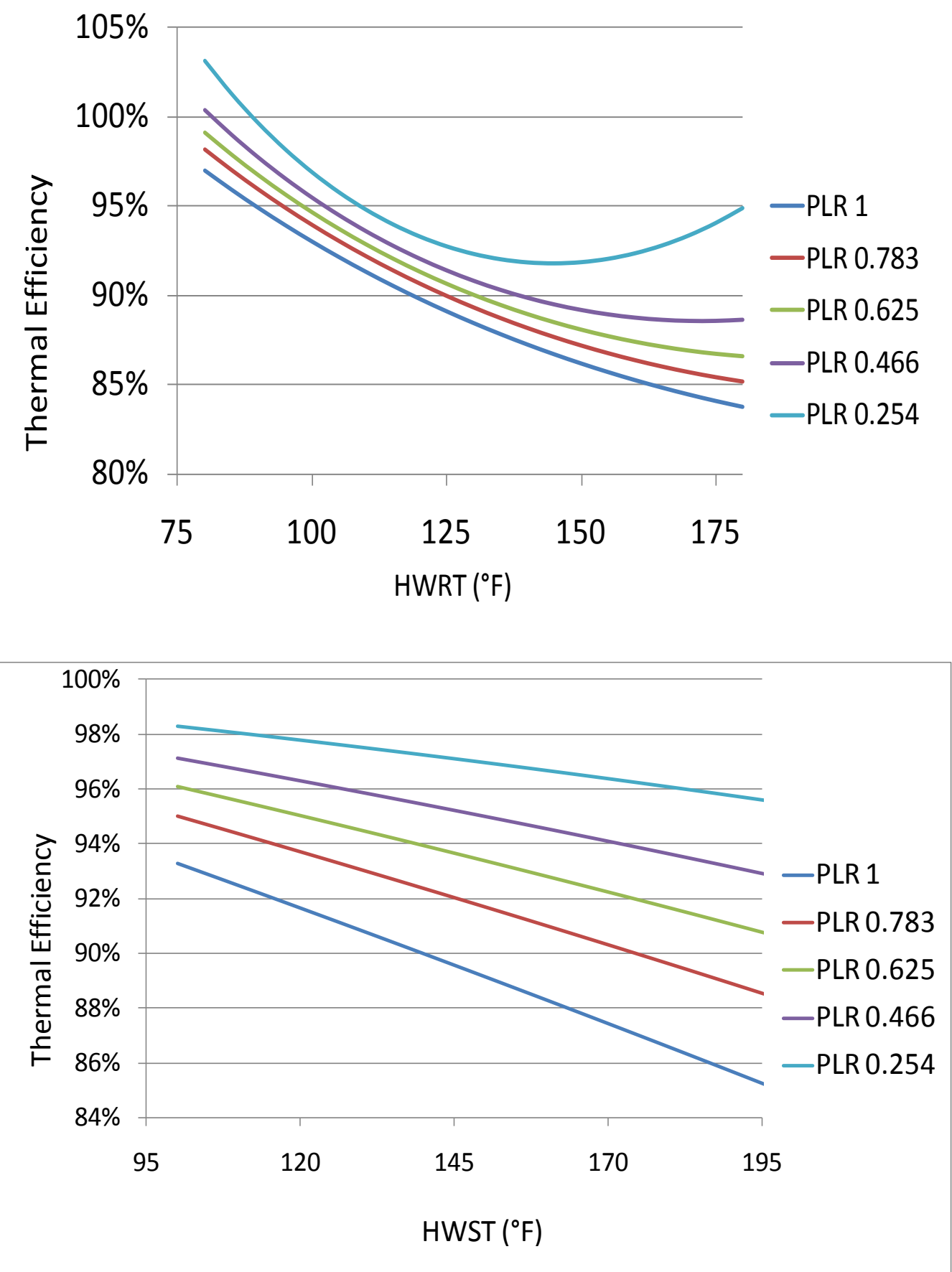


\section{Condensing Performance}

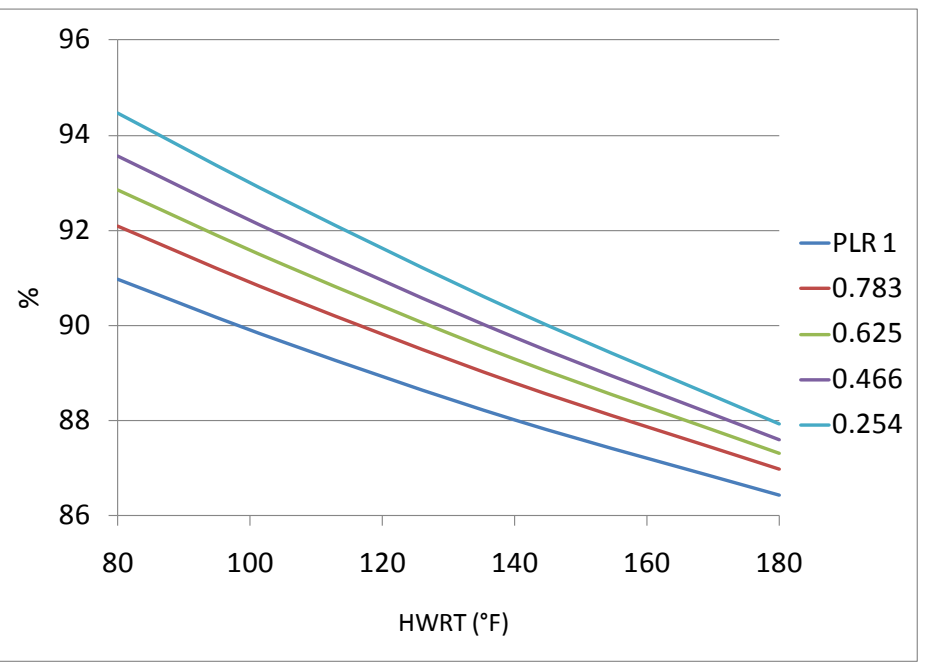

DOE2

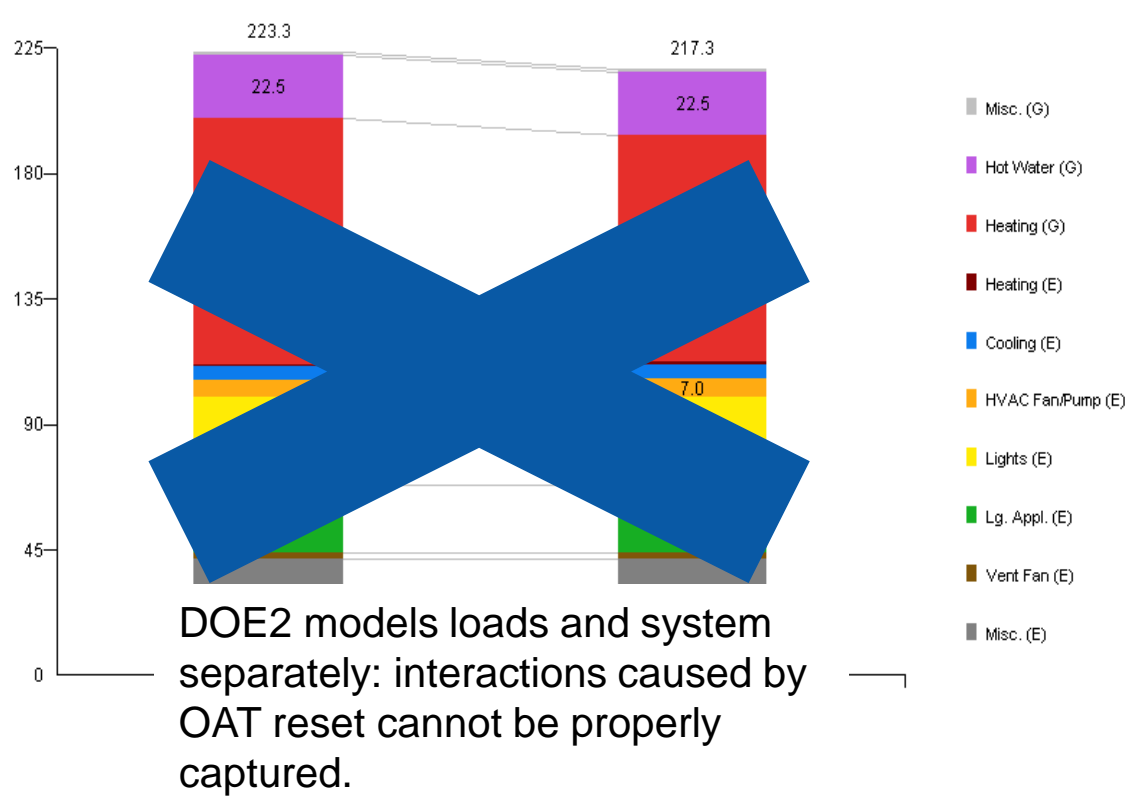

Created a regression fit of Boiler thermal efficiency as biquadratic function of part load ratio and return water temperature.

TE = 87\%@160 F HWRT

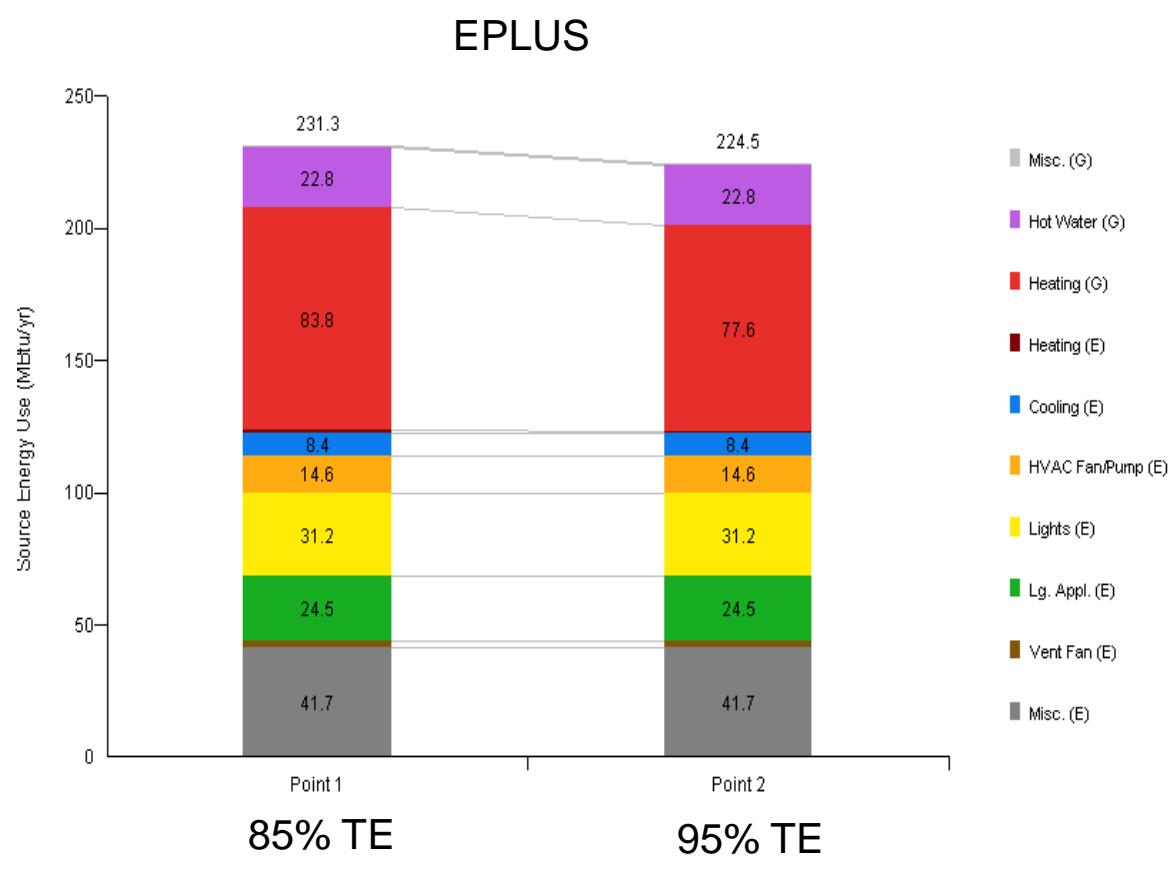




\section{Modeled House Syracuse, NY (EnergyPlus)}

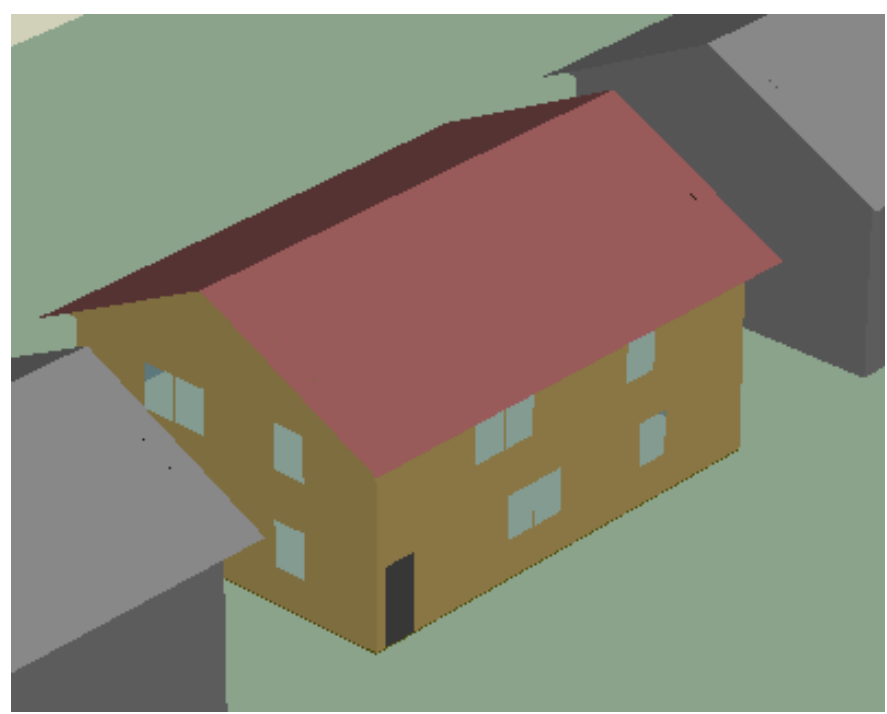

Efficient House
Tightest 1.9ACH50
$2 \times 624$ " OC stud, R21 batts
with 1" foam - R24.2
Vented Attic R60 cellulose
blown in
Low-E Low-SHGC window
CFL lighting, EnergyStar
Appliance
R10 Whole Slab Insulation
Hydronic Heating, SEER 16 AC
Gas Premium Water Heater
EF0.67

\section{Typical House}

\section{Leaky 14.5ACH50}

2x6 24" OC stud, R21 batts with 1" foam - R24.2

Vented Attic R11 cellulose blown in

Dbl-pane Std window

40\% Fluorescent Lighting, Std Appliance

2ft R5 Perimeter

Hydronic Heating, SEER 16 AC

Gas Standard Water Heater EF0.59

Building America House Simulation Protocol assumptions on operating conditions.

Thermostat Setpoint: heating setpoint 71 F w/setback 65 F 11PM - 6AM. 


\section{Control Strategies to Boost Performance}

Claims: "For every $4^{\circ} \mathrm{F}$ the boiler water temperature is reduced, there is a $1 \%$ energy savings. Thus, if the boiler was run based on a fixed set point of $180^{\circ} \mathrm{F}$ vs. running the boiler using outdoor reset at $120^{\circ} \mathrm{F}$ will provide a minimum saving of $15 \% . " . .$.

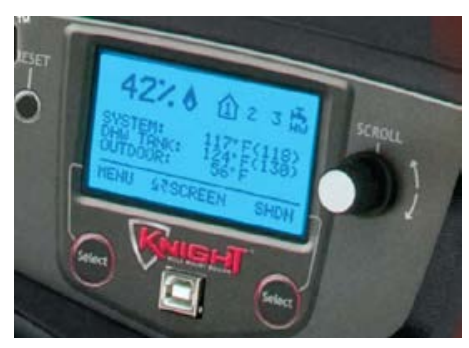

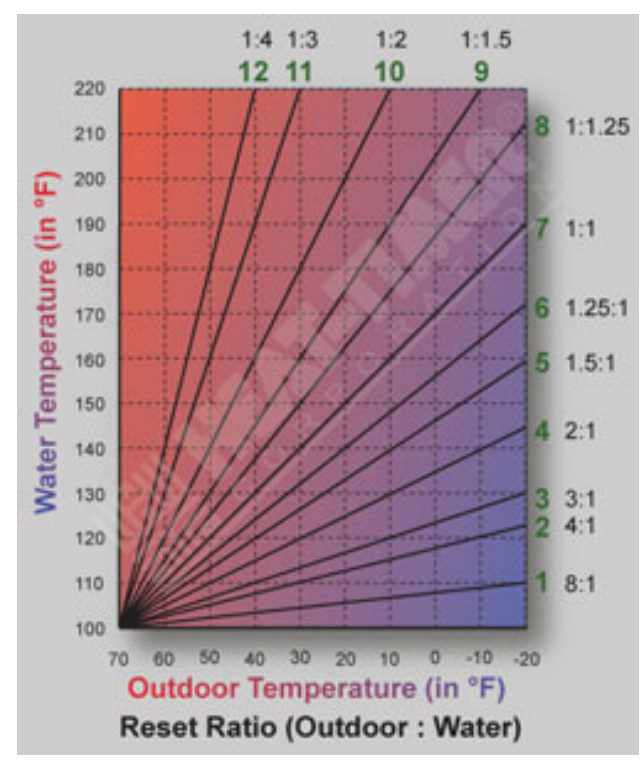

- Baseline 0: Boiler 80\% TE

- Baseline 1: Boiler 85\% TE

- ECM-1: Condensing up to $\sim 95 \%$ Efficient

- ECM-2: ECM-1 + Outside air Temperature Reset

- ECM-3: ECM-2 + 160F HWST Baseboard Doubling Area

- ECM-4: ECM-3 + OAT Reset

- ECM-5: ECM-4+VFD Pumping
Munchkin Boiler Curve $180^{\circ} \mathrm{F}$ Supply @ $5^{\circ} \mathrm{F}$ Outdoor

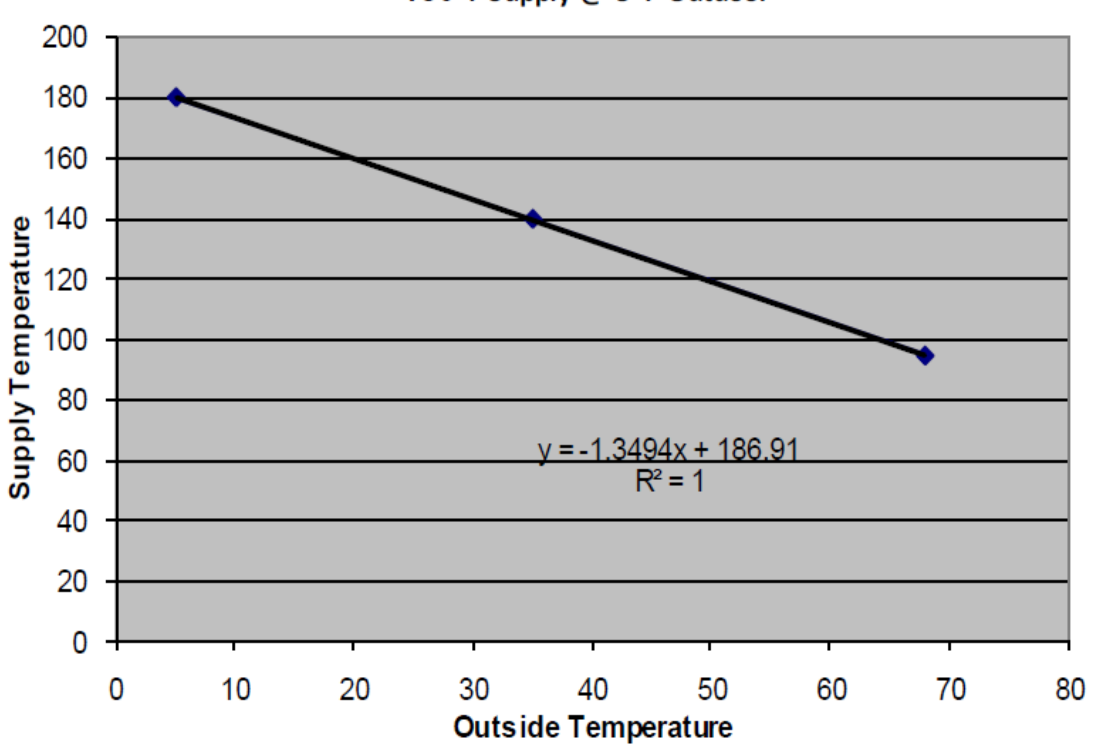

\begin{tabular}{|r|r|}
\hline OAT (F) & HWST (F) \\
\hline 5 & 180 \\
\hline 68 & 95 \\
\hline
\end{tabular}

Note: $95 \mathrm{~F}$ is higher than the monitored houses which drops down to $80 \mathrm{~F}$. 


\section{Convective Baseboards in EnergyPlus}

Convective BB: air is pulled in and out based on natural convection effect.

$$
\begin{aligned}
& \varepsilon=1-e^{\left(\frac{N T U^{0.22}}{C_{\text {ratio }}} e^{\left(-C_{\text {rationTU }} 0.78\right)}-1\right)} \\
& T_{\text {air, outlet }}=T_{\text {air, } \text {, inlet }}+\varepsilon\left(T_{\text {water, } \text {, inlet }}-T_{\text {air, }, \text { inlet }}\right) C_{\min } / C_{\text {air }} \\
& T_{\text {water, outlet }}=T_{\text {water, } \text {,inlet }}-\left(T_{\text {air, outlet }}-T_{\text {air, inlet }}\right) C_{\text {air }} / C_{\text {water }} \\
& \text { Output }(\text { Convective })=C_{\text {water }}\left(T_{\text {water, }, \text { inlet }}-T_{\text {water, outlet }}\right)
\end{aligned}
$$

At the same BB surface area, or heat transfer effectiveness $\varepsilon$ : when boiler supply temp to BB ( $\left.T_{\text {water,inlet }}\right) \downarrow$, BB outlet air temp (Tair,outlet $) \backslash$, and BB leaving water temp $\left(T_{\text {water, outlet })} \mathbf{T}\right.$. This modeling capability in $\mathrm{E}+$ confirms:

-When designing condensing boiler HWST: in order to maintain BB outlet air temp, BB length / surface area needs to be properly increased for lower HWST.

-When operating: convective BB heat transfer effectiveness will change as a result of changing Twater,inlet, resulting in changing Tair,outlet. This effect can be properly captured in EnergyPlus. 


\section{Efficient House Modeled Recovery- Jan $24^{\text {th }}$.}

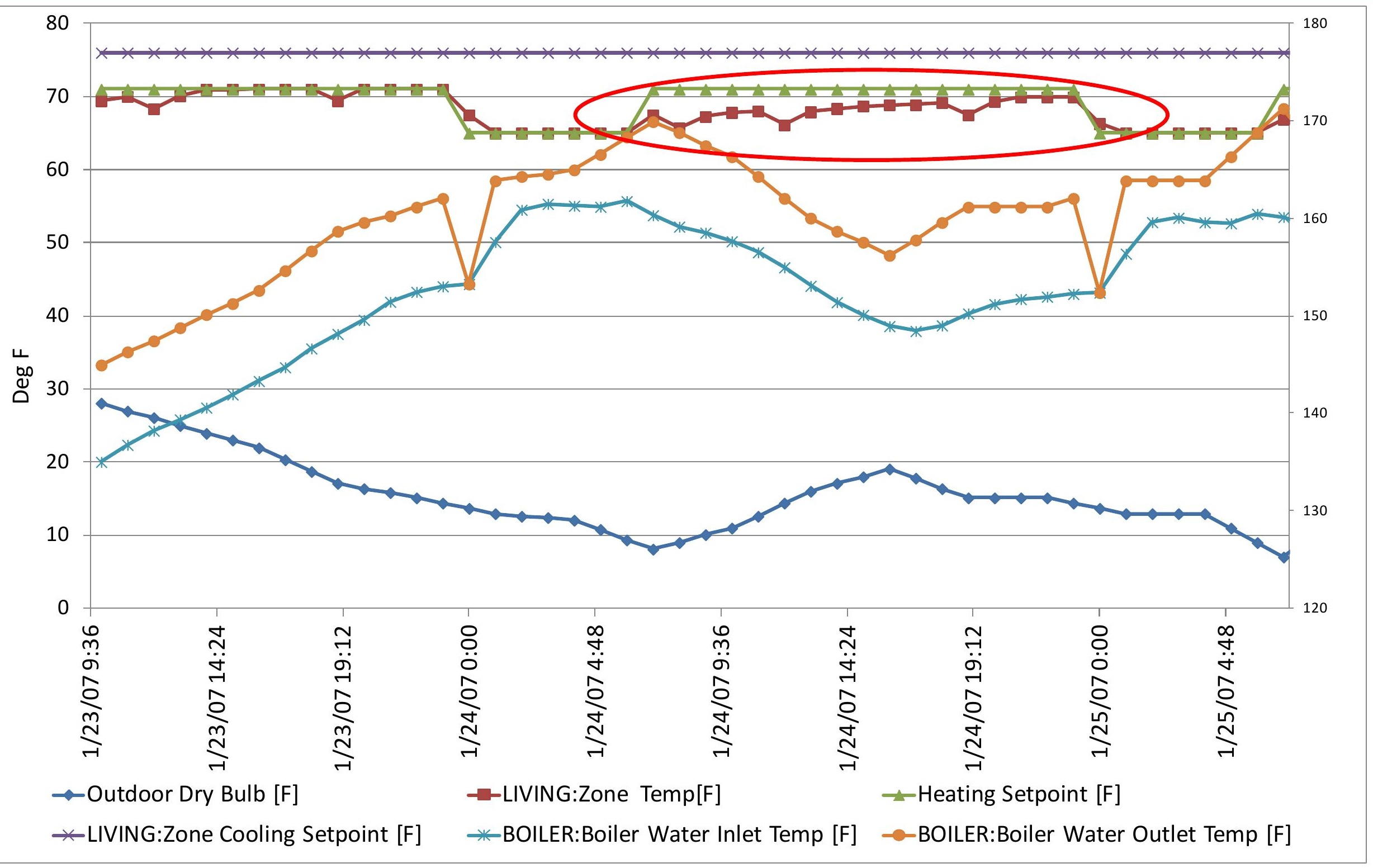




\section{Typical House Modeled Recovery- Jan $24^{\text {th }}$.}

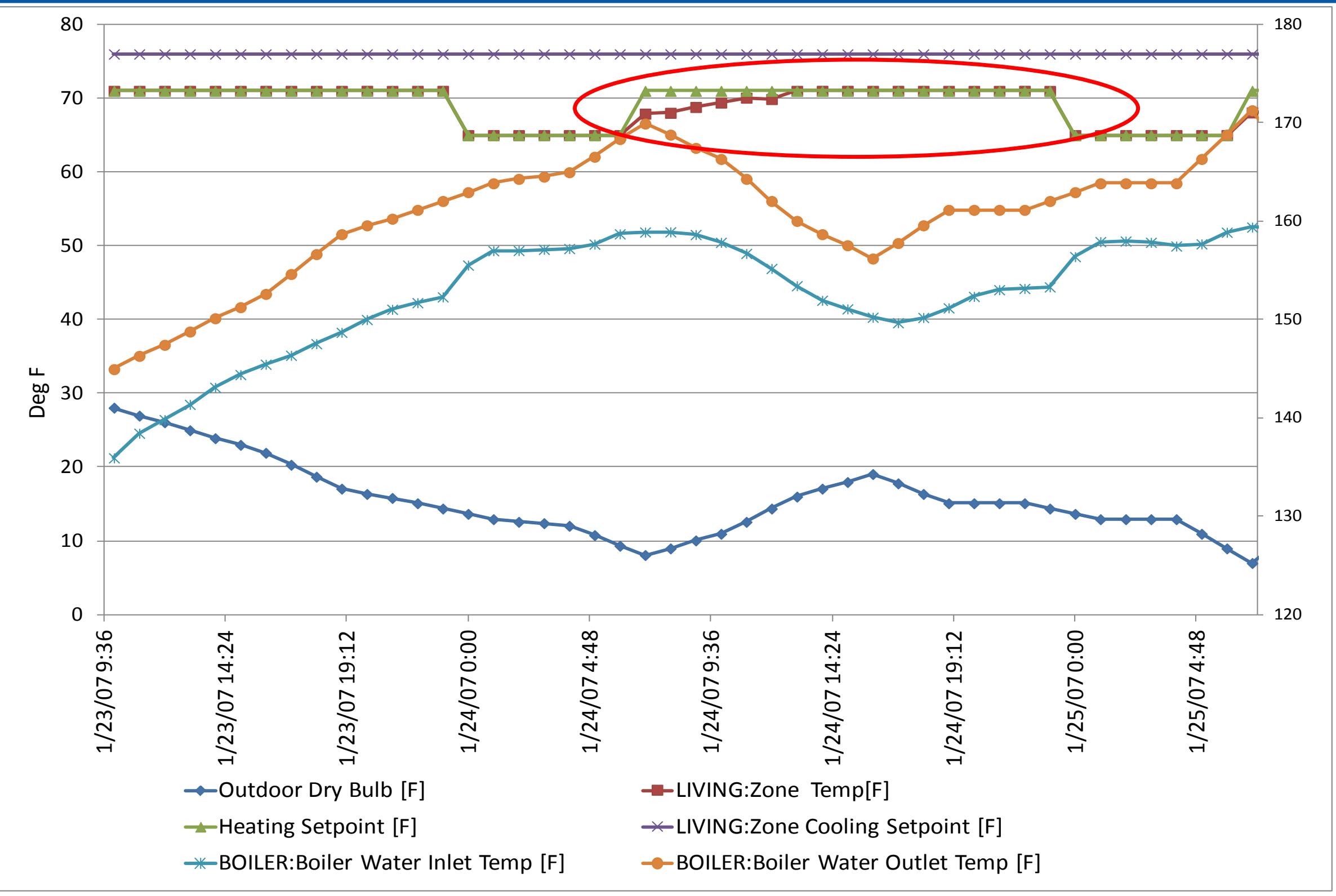




\section{Efficient House Source Energy Consumption}

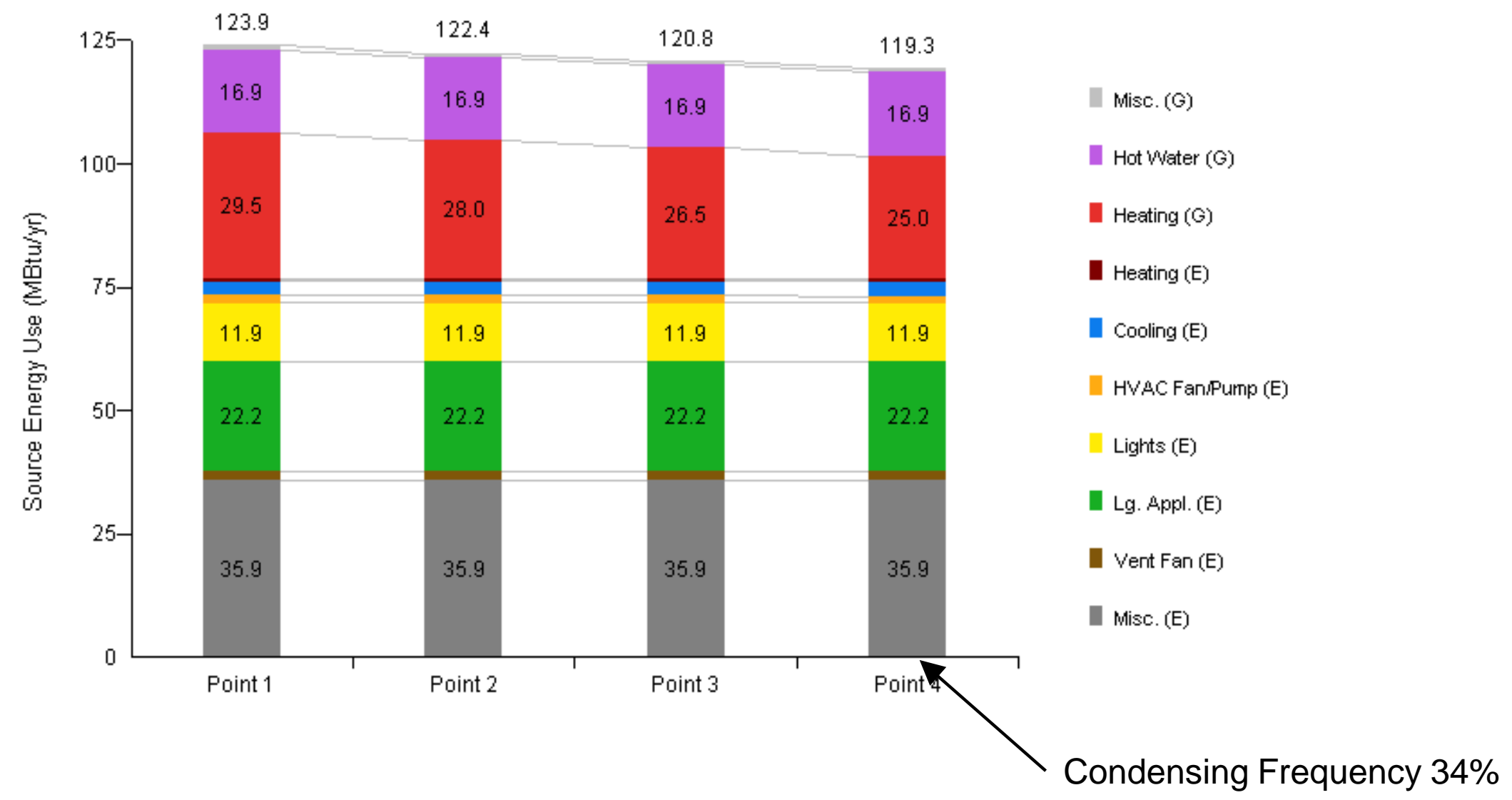

Point 1: Gas 80\% AFUE boiler

Point 2: Gas 85\% AFUE boiler

Point 3: Gas 95\% AFUE boiler, 180F HWST

Point 4: Gas 95\% AFUE boiler, OAT reset on HWST control 


\section{Typical House Source Energy Consumption}

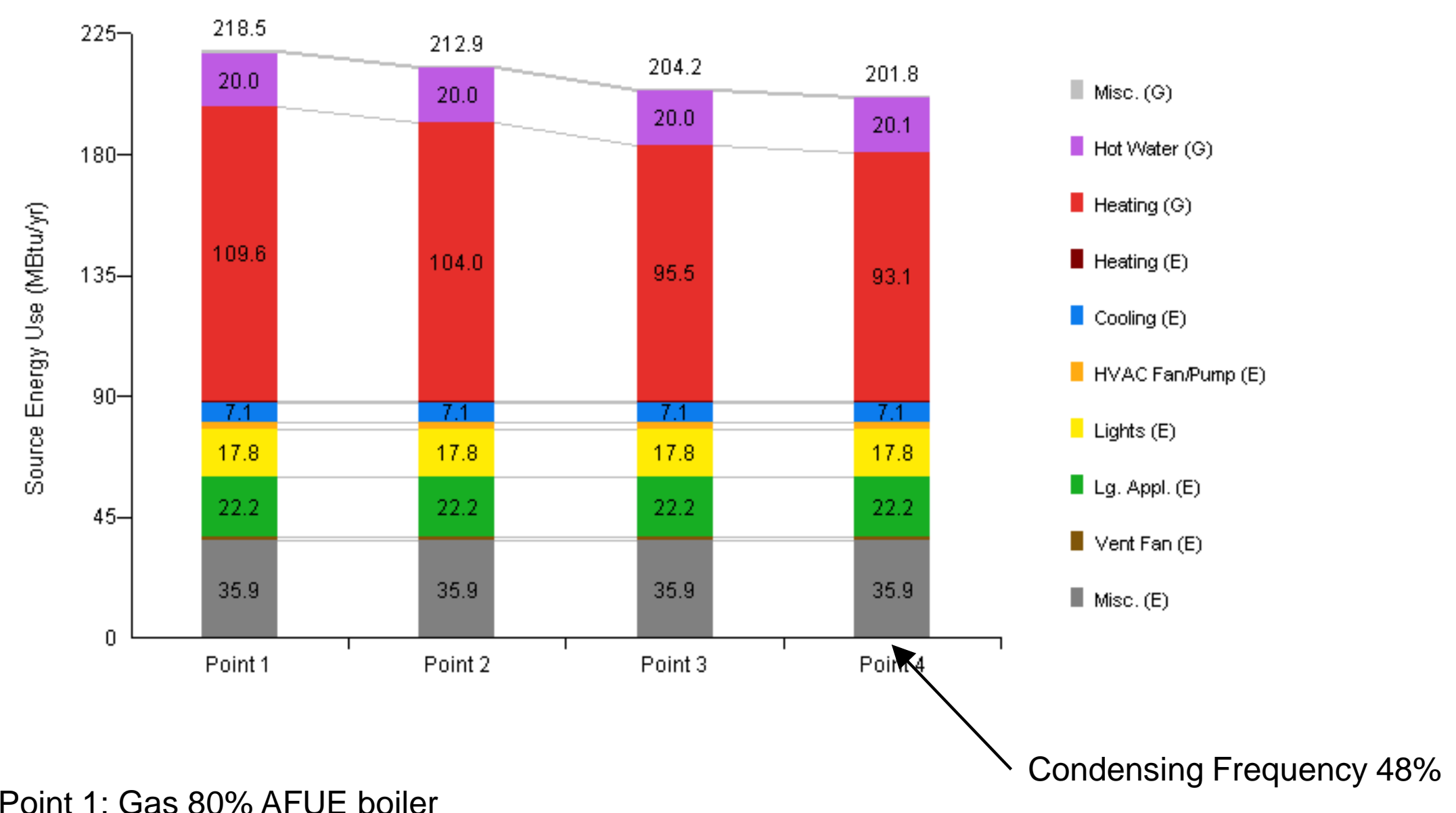

Point 1: Gas 80\% AFUE boiler Point 2: Gas 85\% AFUE boiler

Point 3: Gas 95\% AFUE boiler, 180F HWST

Point 4: Gas 95\% AFUE boiler, OAT reset on HWST control 


\section{Summary}

1. OAT reset increases condensing efficiency when boiler is left at the factory setting of $180 \mathrm{~F}$.

2. OAT reset control on condensing boilers overrides space thermostat reset control, so the boiler does not know to fully fire to catch up the space heating setpoint. This system and load interaction is only captured in EnergyPlus.

3. The problem gets worse in efficient houses where space heating loads are less responsive to OA condition. It's less of a problem in typical houses.

4. To increase condensing frequency without sacrificing thermal comfort, optimization can be further explored among system options of thermostat reset, OAT reset, VFD pumping etc.

5. Condensing boiler savings $\sim 10 \%$ source energy.

6. Future work: zoning for 2 story bldg; space heating and domestic hot water heating combined systems. 


\section{U.S. DEPARTMENT OF Energy Efficiency \& ENERY Renewable Energy}

